\title{
Cooperative Problem Based Learning to Accomodate Learning Disabilities Students in Science
}

\author{
${ }^{1}$ Ayu Rahayu, ${ }^{2}$ Retno Utaminingsih, ${ }^{3}$ Dinar Westri Andini \\ 1ayurahayu.indonesia@gmail.com, ${ }^{2}$ dinar.andini@gmail.com, ${ }^{3}$ qowi_ruh@gmail.com \\ 1,2,3 Universitas Sarjanawiyata Tamansiswa
}

\begin{abstract}
This study aims to reveal how cooperative problem based learning model can accommodate learning disabilities students in science learning in elementary schools. The research method used is descriptive qualitative. The study was conducted at SD Taman Muda Ibu Pawiyatan Yogyakarta. Research subjects were third grade students on odd semester 2018-2019 school year. The results of the study show that through cooperative problem based learning model, groups of students with diverse characteristics are able to work together with the division of tasks according to their competencies. Learning disabilities students are able to follow learning through observation and discussion of science concepts in their cooperative groups. Learning disabilities students are able to convey the application of the science concept in their daily lives.

Key words: cooperative problem based learning, learning disabilities students, science
\end{abstract}

\section{Introduction}

Science is the study of nature and its contents. Science is a body of knowledge, a way of thinking), and a way of investigating[1]. Science is a product or knowledge, process or skill and scientific attitude. Many people, including elementary students, who think science is a difficult lesson. Many people, including elementary students, who think science is a difficult lesson. This is because science is considered a collection of knowledge. Teachers tend to carry out learning in the dimensions of knowledge (products). Assessment also tends to be implemented in the domain of cognitive aspects. Though science is broader than that. The attitude and process dimensions are often forgotten by the teacher.

Several studies on the competence or pedagogical abilities of teachers stated that teachers still had difficulties in preparing RPP (Lesson Plan) including choosing learning strategies and managing classes[2]. Whereas pedagogic ability is one of the determining aspects of learning success.

In addition to problems regarding the preparation of RPP, teachers, especially in the Province of Daerah Istimewa Yogyakarta (DIY), have difficulty managing the class. At present, schools in DIY must accept all students with various backgrounds, including children with special needs. This is in accordance with the inclusive school philosophy. Inclusive schools are schools that do not discriminate between one student and another because they believe that each child has different abilities. Schools must be able to accommodate every child's ability so that children can learn in the true sense.

As mandated by Article 31 of the 1945 Constitution, "Every citizen has the right to education[3]". This means that the state of Indonesia is obliged to provide appropriate education for every citizen, not least. In accordance with the educational principle of $\mathrm{Ki}$ Hadjar Dewantara, education is an effort to humanize humans. School is a place where processes occur in forming real humans[4]. In a narrow sense, this process called learning.

Science learning in the context of thematic learning in the 2013 curriculum is a scientific innovation. Learning is carried out integrative and holistic including the dimensions of 
knowledge (products), attitudes, and skills (processes). Learning must also be varied in order to achieve these holistic competencies.

Variations in learning by teachers are carried out to accommodate students' different learning styles, including students with learning disabilities. Learning disabilities are children's inability to learn. The word "disabilities" itself means difficulty, this is used as an impression that the child is actually able to learn through various ways. LD or commonly referred to as special learning difficulties due to a neurological disorder or minimal brain dysfunction, where the child experiences perceptual disturbances so that it will be difficult to understand information both visually and auditory.

One of the inclusive primary schools in DIY is SD Taman Muda Ibu Pawiyatan. Primary school teachers here have difficulties in developing learning for students in inclusive schools, especially LD students. Therefore, it is necessary to carry out variations of learning. One variation of learning that is done is the integration between problem based learning (PBL) and cooperative approach. PBL is learning gained through a process towards understanding the resolution of a problem[5]. The problem is first met in the learning process. PBL is a form of transition from the paradigm of teaching to the paradigm of learning or learning in PBL emphasizing student centered. In PBL students are more active in the learning process while the teacher is no longer the center of learning but as a facilitator. There are 3 basic elements that must appear in PBL, namely initiating trigger / initiating triggers, examining previously identified issues and utilizing knowledge in further understanding the problem situation[5].

PBL learning syntax is as follows [6]. 1) Serve a problem to students. 2) Discuss the problem in the PBL tutorial in a small group whose activities include clarifying the facts in a case, defining the problem, brainstorming ideas that are based on prior knowledge, identifying the things used to solve the problem, reviewing the existing problems and design an action plan to deal with the problem. 3) Independent study to solve problems beyond teacher guidance. 4) Sharing information through peer teaching or cooperative learning on certain problems. 5) Students present solutions to existing problems. 6) Students review what they learn during the learning process.

In solving problems, students work together in heterogeneous groups. This heterogeneous group consists of the ability of students who are diverse and good students who have abilities above average and students who need help in learning (learning disabilities). The cooperative approach is implemented as a divider between students who have abilities above average with students with special needs.

Cooperative learning is a group learning with ideas and motivating each other among its members to help each other so that learning goals are achieved[6]. Cooperative learning is a learning strategy through small groups of students who work together to maximize learning conditions for learning purposes. The syntax of cooperative learning is: (1) Delivering goals and motivating students, (2) Presenting information, (3) organizing students into groups learning groups, (4) guiding working and learning groups, (5) evaluating, and (6) giving appreciation.

PBL-based and cooperative learning is integrated in order to accommodate each student's learning needs. Through Cooperative problem based learning, groups of students with diverse characteristics are able to work together with the division of tasks according to their competencies. SD Taman Muda IP is one of the inclusive schools that have implemented CPBL learning. Based on this, research on cooperative problem based learning to accommodate learning is needed in students' disabilities in science at SD Taman Muda IP. The research will reveal how CPBL learning steps and examples of descriptions of their implementation in learning. 


\section{Material \& Methodology}

\subsection{Method}

The research was carried out with qualitative descriptive method. The study was conducted in July at SD Taman Muda Ibu Pawiyatan. The subjects of this study were third grade students of odd semester 2018/2019 school year.

\subsection{Data}

Data collection is carried out with observation and documentation techniques. The research instrument used was observation sheets and interviews so that data was collected on how cooperative problem based learning was carried out to accommodate LD students.

\section{Results and Discussion}

\subsection{Result}

Observation of learning is carried out for Class III Semester 1 in Theme 1 (Animal and Plant Breeding) with Subtema 2 (Plant Breeding). In the first learning, the learning material presented is how to care for plants. The second learning material is the "plant breeding method" and the third learning is the "plant life cycle". The integration of cooperative learning syntax and problem based learning in learning 1 , learning 2 , and learning 3 are shown in Table 1, Table 2, and Table 3.

\begin{tabular}{|c|c|c|}
\hline Cooperative Learning Syntax & Learning steps & $\begin{array}{c}\text { Problem Based Learning } \\
\text { Syntax }\end{array}$ \\
\hline $\begin{array}{l}\text { (1) Conveying goals and } \\
\text { motivating students }\end{array}$ & $\begin{array}{l}\text { The teacher conveys the expected competencies, indicators of } \\
\text { achievement of competencies and learning objectives. } \\
\text { The teacher motivates students and attracts students' attention } \\
\text { by singing the song "Bungaku" } \\
\text { The teacher conveyed the apperception regarding the material } \\
\text { on how to take care of the plants and gave an explanation of } \\
\text { the benefits of studying the material. }\end{array}$ & \\
\hline (2) Presenting information & $\begin{array}{l}\text { The teacher displays images of wilted and dead plants and } \\
\text { fresh and alive plants. } \\
\text { Students observe and pay attention to the picture (observing) } \\
\text { Teachers and students ask questions and answers about the } \\
\text { differences in the plant and the teacher asks why the plant can } \\
\text { wither and die (asking question) }\end{array}$ & $\begin{array}{l}\text { (1) Student orientation } \\
\text { on problems }\end{array}$ \\
\hline $\begin{array}{l}\text { (3) organize students into } \\
\text { groups - study groups }\end{array}$ & $\begin{array}{l}\text { Students are divided into cooperative groups. Each group } \\
\text { shared the worksheet to find problems related to the condition } \\
\text { of the plant. Students with teachers prepare tools and materials } \\
\text { that will be used to practice caring for plants. Students are } \\
\text { invited to the school garden to practice how to care for good } \\
\text { and right plants so that the plants do not wither and die. }\end{array}$ & $\begin{array}{ll}\text { (2) } & \text { Organizing } \\
& \text { students to learn }\end{array}$ \\
\hline \multirow[t]{2}{*}{ (4) guiding study groups } & $\begin{array}{l}\text { The teacher provides instructions and direction to students in } \\
\text { practicing how to care for plants Each group practices how to } \\
\text { care for plants that are good and right (try) }\end{array}$ & $\begin{array}{l}\text { (3) Guiding individual } \\
\text { / group experience }\end{array}$ \\
\hline & $\begin{array}{l}\text { Students observe and record ways and steps in caring for } \\
\text { a good and right plant (observing) } \\
\text { Each group discussed the results of their practical } \\
\text { activities in caring for the plants (associating) } \\
\text { Each group presents the results of their work in front of } \\
\text { the class on how to care for the right plants } \\
\text { (communicating) }\end{array}$ & $\begin{array}{l}\text { (4) Develop and } \\
\text { present the work }\end{array}$ \\
\hline
\end{tabular}




\begin{tabular}{|l|l|l|}
\hline (5) evaluation & $\begin{array}{l}\text { Other students respond to groups who present on how to } \\
\text { care for plants (communicating) }\end{array}$ & $\begin{array}{l}\text { (5) } \\
\text { Analyze and } \\
\text { evaluate the } \\
\text { problem solving } \\
\text { process }\end{array}$ \\
\hline (6) giving awards & $\begin{array}{l}\text { Students who advance the presentation are given awards } \\
\text { (prizes) } \\
\begin{array}{l}\text { Students with teachers together discuss how to care for } \\
\text { plants that are good and right from the results of the } \\
\text { discussion of all groups (associating) }\end{array}\end{array}$ \\
\hline
\end{tabular}

Table 1. Cooperative problem based learning in the material "how to care for plants"

Table 2. Cooperative problem based learning in the material "how to breed plants"

\begin{tabular}{|c|c|c|}
\hline $\begin{array}{l}\text { Cooperative Learning } \\
\text { Syntax }\end{array}$ & Learning steps & $\begin{array}{l}\text { Problem Based Learning } \\
\text { Syntax }\end{array}$ \\
\hline $\begin{array}{l}\text { (1) Conveying goals and } \\
\text { motivating students }\end{array}$ & $\begin{array}{l}\text { The teacher conditions students to follow the learning } \\
\text { process, The teacher asks the class leader to prepare and lead } \\
\text { the prayer, The teacher conducts attendance towards students } \\
\text { The teacher conveys the expected competencies, indicators of } \\
\text { achievement of competencies and learning objectives, The } \\
\text { teacher motivates students and attracts students' attention by } \\
\text { singing "View My Garden", The teacher conveyed the } \\
\text { apperception related to material about plant breeding and } \\
\text { explained the benefits of studying the material. }\end{array}$ & \\
\hline $\begin{array}{l}\text { (2) Presenting } \\
\text { information }\end{array}$ & $\begin{array}{l}\text { The teacher asks students, "Why can the number of plants } \\
\text { increase?" (Ask), Students discuss with their friends to find } \\
\text { answers to the teacher's questions. (associate), Students try to } \\
\text { answer questions from the teacher and the teacher straightens } \\
\text { out if there is an incorrect answer (communicates) }\end{array}$ & $\begin{array}{l}\text { (1) Student orientation } \\
\text { on problems }\end{array}$ \\
\hline $\begin{array}{l}\text { (3) organize students } \\
\text { into groups - study } \\
\text { groups }\end{array}$ & $\begin{array}{l}\text { The teacher tells students that plants can multiply because of } \\
\text { breeding, The teacher presents a video about plant breeding. } \\
\text { Students are divided into observation and discussion groups. } \\
\text { Each group is distributed by LKS to find problems related to } \\
\text { plant breeding, Students are invited to the school gardens and } \\
\text { the environment around the school to identify and classify the } \\
\text { ways in which plants are grown }\end{array}$ & $\begin{array}{l}\text { (2) Organizing students } \\
\text { to learn }\end{array}$ \\
\hline \multirow[t]{2}{*}{ (4) guiding study groups } & $\begin{array}{l}\text { The teacher gives instructions and direction to students in } \\
\text { making observations in the school environment, Students } \\
\text { explore nature around the school in groups to classify the way } \\
\text { plants grow (try) }\end{array}$ & $\begin{array}{l}\text { (3) Guiding individual } \\
\text { / group experience }\end{array}$ \\
\hline & $\begin{array}{l}\text { Students observe and record and classify how plants } \\
\text { reproduce (observe), Each group discussed the results of its } \\
\text { observations on the field on plant breeding material } \\
\text { (associate), Each group presents their work in front of the } \\
\text { class (communicating) }\end{array}$ & $\begin{array}{l}\text { (4) Develop and } \\
\text { present the work }\end{array}$ \\
\hline (5) evaluation & $\begin{array}{l}\text { Other students respond to groups who are presenting about } \\
\text { plant breeding (communicating) }\end{array}$ & \multirow{2}{*}{$\begin{array}{l}\text { (5) Analyze and } \\
\text { evaluate the } \\
\text { problem solving } \\
\text { process }\end{array}$} \\
\hline (6) giving awards & $\begin{array}{l}\text { Students who progress presentations are awarded (prizes) } \\
\text { Students with the teacher together discuss the results of their } \\
\text { observations in identifying and classifying the way plants } \\
\text { grow (associate) }\end{array}$ & \\
\hline
\end{tabular}

Table 3. Cooperative problem based learning in the "plant life cycle" material 


\subsection{Discussion}

In cooperative-problem based learning, students are grouped into study groups. This learning group is a cooperaive group consisting of various kinds of student abilities, ranging from students with abilities above average to learning students with disabilities. It is known that, in Class III SD Taman Muda Ibu Pawiyatan there are LD students. Both students showed a lack of ability to read, write and count ${ }^{[8]}$.

In the first learning about "how to care for plants", LD students can follow the learning well. Learning is mostly carried out outdoors. Students practice how to care for plants by removing dry parts of plants and watering plants. Students are very happy to take the first lesson. Students can express their opinions about how they care for plants at home.
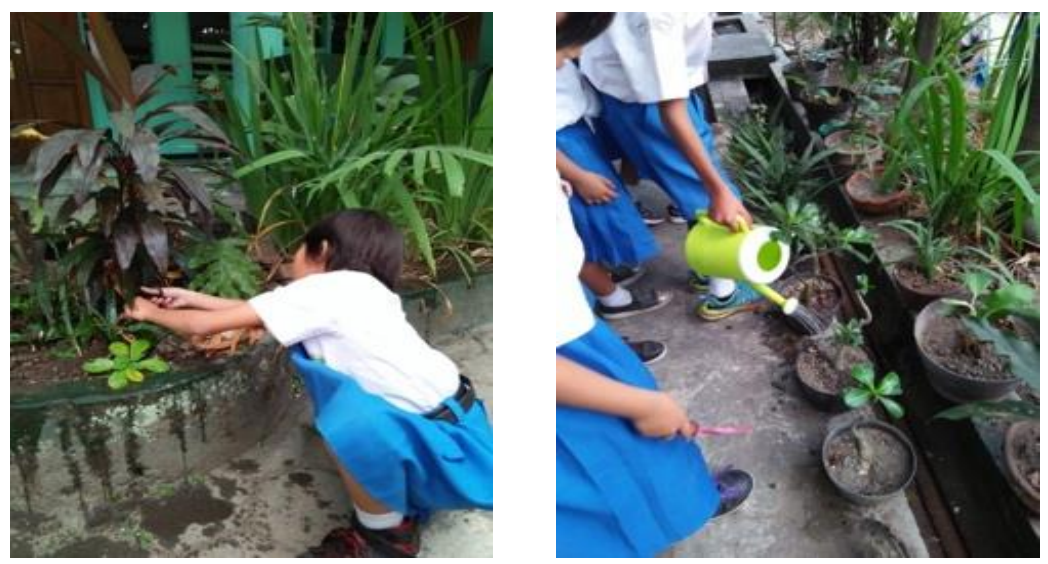

Figure 1. Students practice how to care for plants

The second learning about plant breeding is carried out in class. Students are facilitated with LKS and concept map learning media. Students work on LKS together in their groups. In the group, LD students can work well together. Other friends can understand that LD students have not been able to write smoothly and remember the learning material is rather slow, so that friends in the group help LD students.

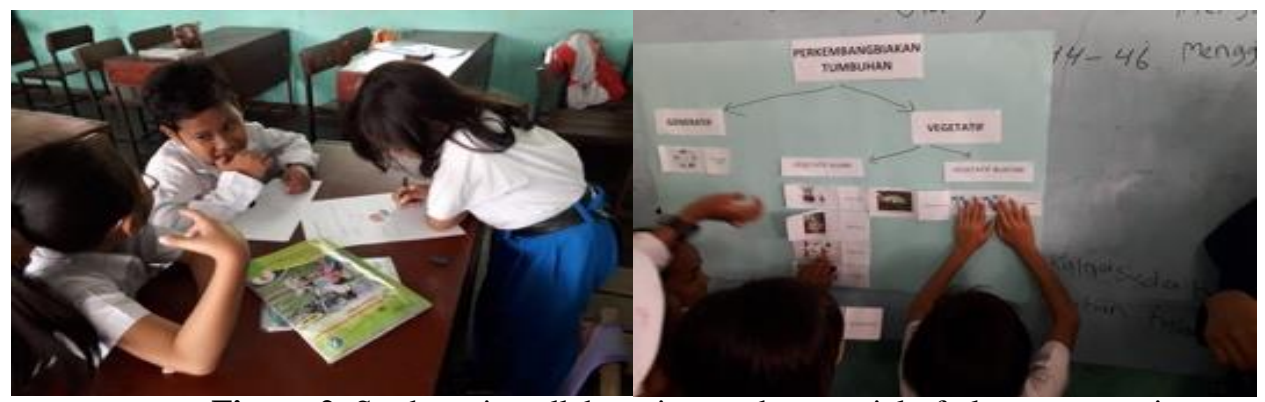

Figure 2. Students in collaboration study material of plant propagation

In the third study, students learn about the life cycle of plants, namely sprouts. Students are given pictures that represent the growth phase of the sprouts, namely seeds, small sprouts and large sprouts. LD students can follow the learning well in the cooperative group. 

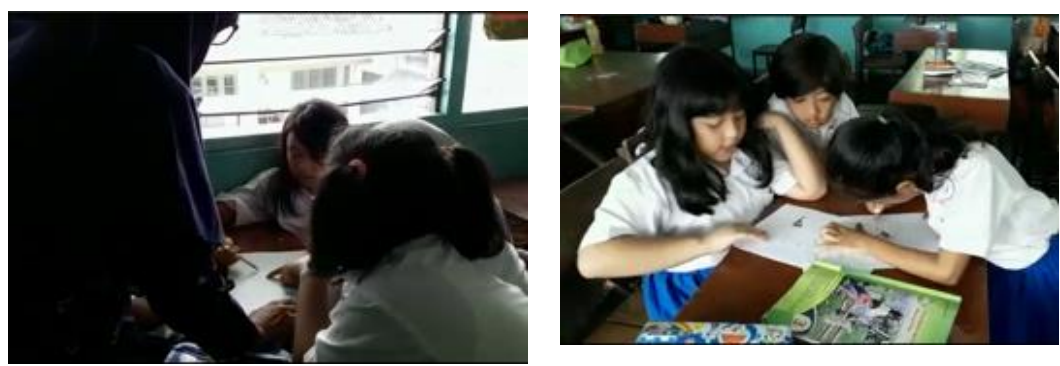

Figure 3. Students cooperate in cooperative groups with teacher guidance

\section{Conclusion}

Based on the discussion, it can be concluded that through cooperative problem based learning, groups of students with diverse characteristics are able to work together with the division of tasks according to their competencies. Learning disabilities students are able to follow learning through observation of symptoms and discussion of simple science concepts in their cooperative groups. Learning disabilities students are better able to convey the application of the science concept to their daily lives.

\section{Acknowledgement.}

This research is fully supported by Research Grant of Penelitian Dosen Pemula DRPM DIKTI 2018.

\section{References}

[1] T. . Chiappetta, E.,L. \& Koballa Jr, Science Instruction in The Middle and Secondary Schools Developing Fundamental Knowledge and Skills. Boston: Allyn \& Bacon, 2004.

[2] D. W. Andini, Model Adaptasi Kurikulum dan Perangkat Pembelajaran. Yogyakarta: LP3M Universitas Sarjanawiyata Tamansiswa, 2018.

[3] Undang-Undang Dasar Republik Indonesia tahun 1945 pasal 31. .

[4] Dewantara, Karya Ki Hadjar Dewantara Bagian Pertama Pendidikan. Yogyakarta, 2011.

[5] M. Huda, Model-Model Pembelajaran dan Pengaran. Yogyakarta: Pustaka Pelajar, 2013.

[6] Rininingsih, Model-Model Pembelajaran yang Disarankan dalam Kurikulum 2013. Yogyakarta: Universitas Muhammadiyah Purwokerto, 2017. 